Arts \& Humanities | Elara Bertho \& Marie Rodet

\section{The historical writings of Djiguiba Camara (Guinea)}

Dr Elara Bertho, of the French National Centre for Scientific Research, and Dr Marie Rodet, at SOAS University of London, have rediscovered, studied, edited, and annotated the historical work of Djiguiba Camara (c. 18851963), a writer and historian from Upper Guinea. Camara's fascinating local history, "Essai d historre locale", Was used whout direct acknowledgement by Fren historian W'es Person more than fifty years ago, and retrieved by with Camara's family, the research investigation and publication process have raised vital questions about postcolonial agency, historiography, knowledge production, power and authorship.
rElara Bertho, of the French
National Centre for Scientific Research, and Dr Marie Rodet, at dited, and annotated a 110-page ipt written by Guinean

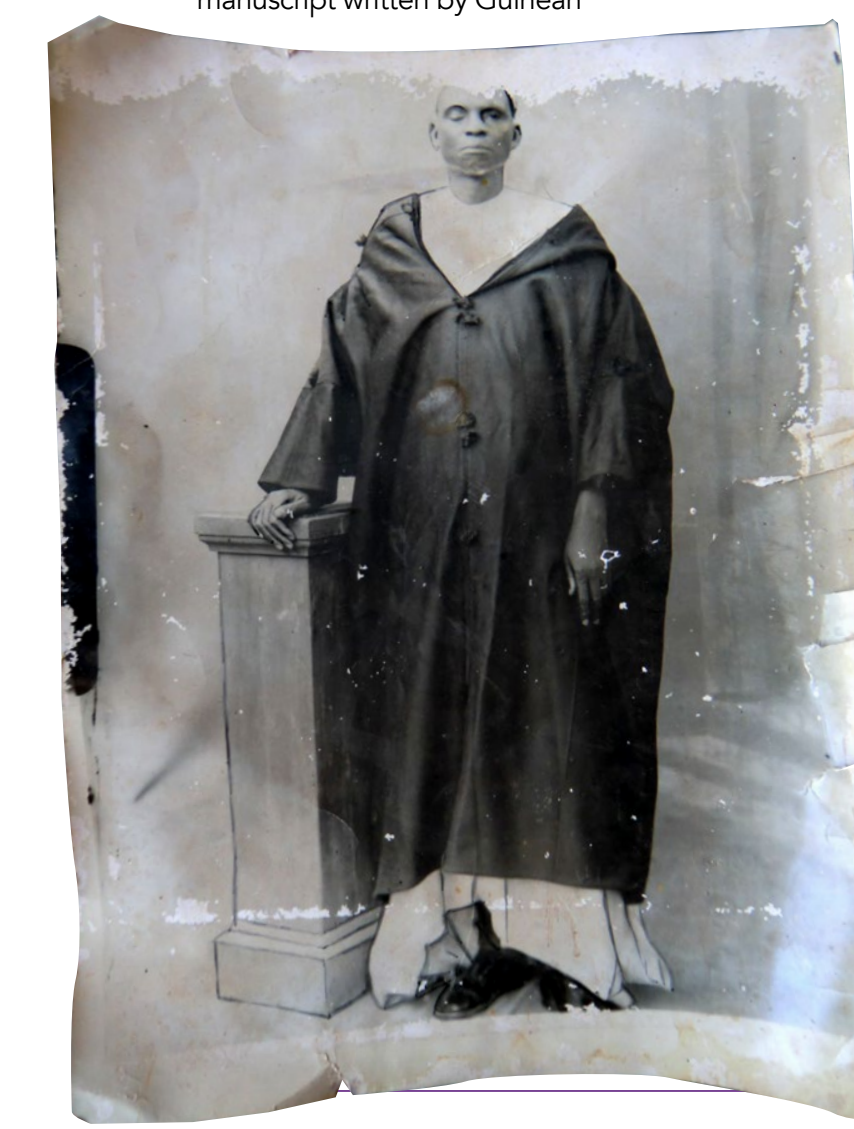

(as Camara had been appointed a distric commissioner in 1928). Intermedia maintained (unequal) cors', as they bridges between coloniser and colonised.

Ronald Robinson has described how the 'bargain of collaboration' enabled some colonial subjects - in particular intermediaries - to accumulate power and fortune, while offering a certain number of 'services' to the colonial administration (Robinson, 1972). This involved production of knowledge about indigenous societies. However, these contributions remained unofficial, and intermediaries have only rarely been recognised as co-producers of knowledge by Western recipients, including explorers, soldiers, missionaries, administrators, and ethnographers (Tilley Q Gordon, 2007;

At the end of the Second World War this type of 'collaboration' entered a Western researchers aimed to produce knowledge with a view of 'modernising' colonial Africa. However, the contribution of Africans has still not received sufficien recognition, as proven by the ignorance of Djiguiba Camara's historical scholarship until its publication by Rodet and Bertho in 2020

\section{LIFE OF DJIGUIBA CAMARA:} THE TRAJECTORY OF A COLONIAL INTERMEDIARY AND D GUNEAN SCHOLAR Fjiguiba had a long and eventful career were seen as 'cultural mediators' new phase, as a growing number of the Banque de l'Afrique Occidentale at . Conakry branch. In 1928, he replaced based in the village of Damaro, his birthplace. In 1946, Diiguiba stood for the first time for election to the Conseil Général, but received very few votes in his canton. He was seen as "authoritarian and proud". Reform of the repressive colonial system wh gradually introduced, including the abolition of forced labour in French West Africa in 1946. In 1952, however Djiguiba was elected to the Territoria Assembly as Paul Téteau's deputy on the list for the "Defence of Rural Interests". Following Téteau's death 1952, Djiguiba Camara replaced him Antil further elections took place on 2 August 1953 These elections were won by Sekou Toue, the future fist President hat Diguiba started his political career in Beyla as one of Sékou Touré's mer opponents. Dijguba had begun writing "Essai d'histoire locale" in 1928 when he was appointed canton chief, and he continued writing it until his death in 1963. Djiguiba Camara used his scholar's position and his writings to legitimate his local position in a fast-changing political landscape.

\section{THE MANUSCRIPT: A MAJOR}

SOURCE FOR AFRICAN HISTORY Djiguiba Camara began writing his text in 1928 and completed it in 1955, with the intention of having it published. French historian, who collected a drechistorian, who collected and recorded from the communities for $h$ is PhD thesis published in three seminal volumes in 1968, 1972, and 1975 . Person was among the first Europea historians of Africa to compare colonital sources with African oral traditions. Person in his bibliography only wrote down the names of the main speakers with some notes on the interviews he conducted with 'privileged sources'. Djiguiba Camara appeared as his main 'privileged source', but the 110 page manuscript of "Essai d'histoire personal papers.

Camara's text can be seen as a hybrid ced by oral tradition, genealogies, epic, and colo cale" actually appeared in Person's

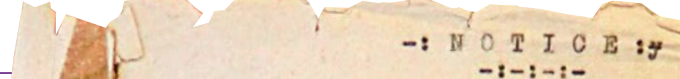

$$
\text { A MON ANI }
$$

Je Jo n'ai pas voulu passer inaperçu. Il n'y a pas d'or-

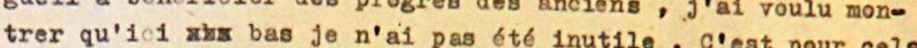

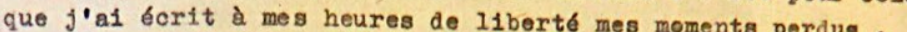
Jal ecrit sur le passé de nos pères en ce coin a dueri Les SOCWIACA . 11s nous manifestent les originalités mesmes de notre pays. Jal voulu obacher un travall ardu; J'al essayé de jeter

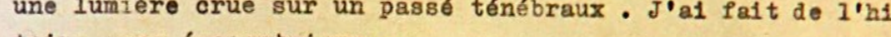
des conceptions europénnes, notre passé tend aे s'incorporer à une histoire générale, des voix s'élèvent, des hompos s les mitares de nos aĩeux.

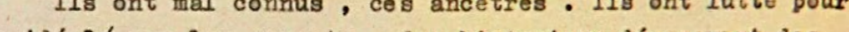

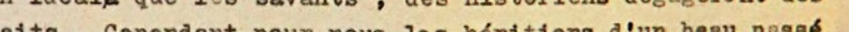

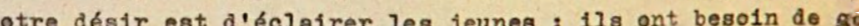
作 Con lnexorable optimisme, introduit des moeurs nouvelles

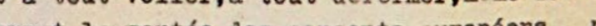
n'est pas d'opposer une résistanco (passive ou active), mals Catter a nous oompronire pour nous atmer.

son histoire.

Bt, oette h1s
tres deverloppent.

de dégager une ét1tée rég1onale, de ral

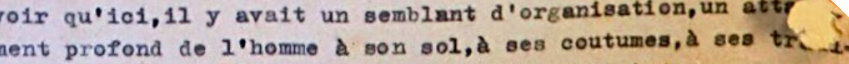

(1)

The authors place Camara's work as a counter-history to the weight of French colonial writing.

model of historical writing. Yet it doesn't fall fully into one of these categories as Djiguiba Camara uses these multiple and rich legacies of history telling and writing to legitimate his position
scholar in a colonial context.

The presence of Djiguiba Camara's manuscript in Person's personal papers, with no specific reference as a source text in his PhD thesis, also points to uses (and abuses) of local knowledge and authorship that were common during the colonial era. Kes Person conducted administrator in Upper Guinea Can admistratorin Upper Guinea. Camara's of the Camara, the wars of Samoni onsergnement cirique que dar has accused Yves Person of extracting the work from him in exchange for what turned out to be a false promise that it would be published in France. The by Caseen as a vital family patrimony 作 Daouda continued to edit and expand upon his father's work until today.

The text discusses the family migrations Toure, the colonial conquest, and covers the perod up unt 1955. A ter careful study of the manuscript, Dr Bertho and Dr Rodet got closely engaged with 


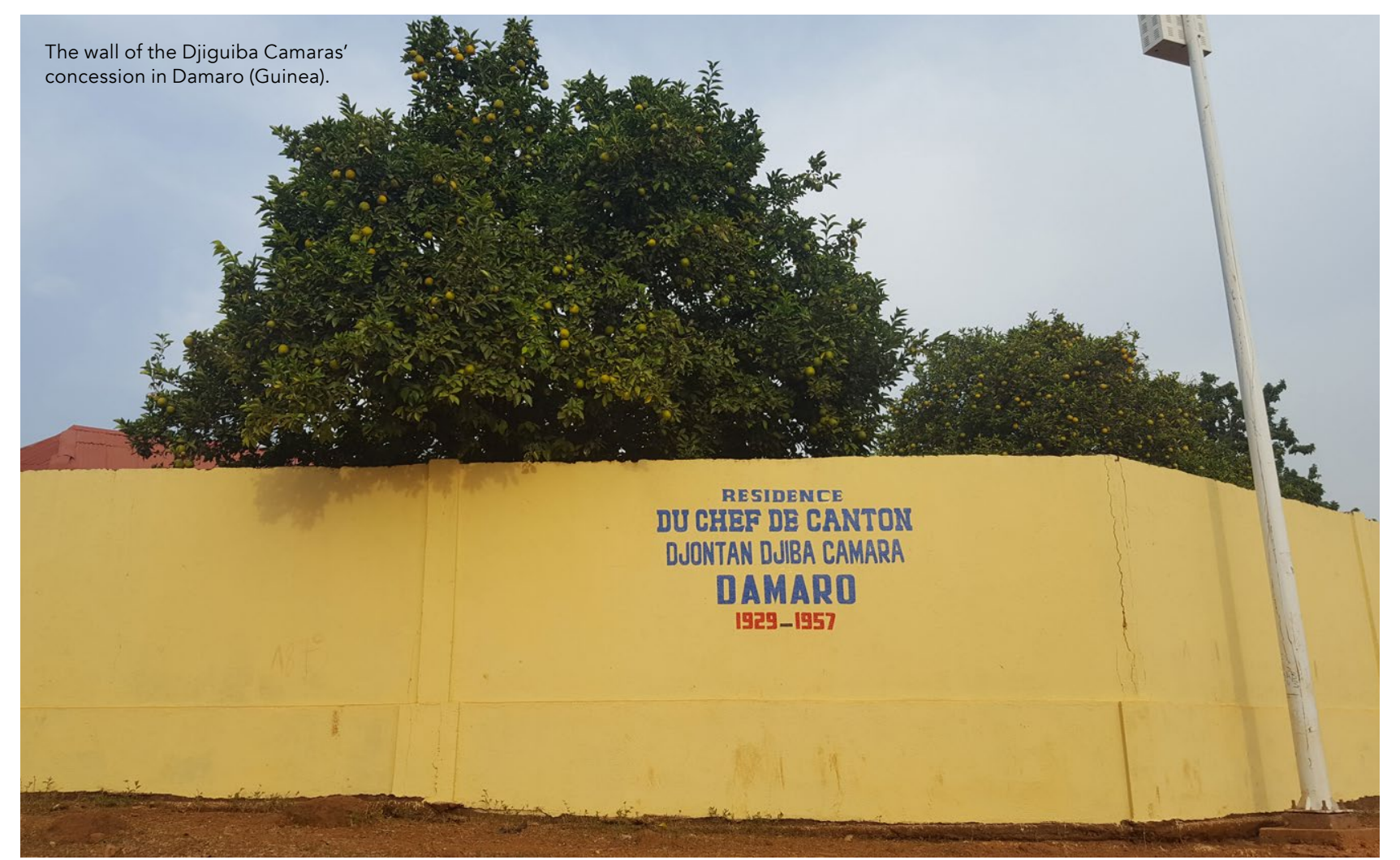

work, and adopted a transdisciplinary literature, and oral intenview.

negative experience with Person. They

ollowed the project as it progressed. literature, and oral interview. threatened the researchers with a lawsult. regularly via email and telephone, and counter-history to the weight of Fren colonial writing. They argue that Djiguiba Camara's trajectory and his historical Nevertheless, in 2015, the researchers established a rapport with El Hadj Daouda Damaro Camara, and they travelled to Conakry and Damaro to interview him. El Hadj commented ( 2018, and then again in April of 2018 .

Each time, El Hadj Daouda Damaro Camara recounted his father's story, a broader colonial history, and are centred around his position.

Publishing such text in open access is a vital means of recognising the value producing an of local historians and reasserting the the family and the family and region's history. As a rext analyses the uses of Publishing such text in open access recognising the value of local historians importance of silenced African voices and local and family neglected sources for the history of the African continent.

and reasserting

of silenced African voices and neglected sources for the history of the African continent.

WORKING WITH THE FAMILY TO RECOGNISE POSTCOLONIAL POWER IMBALANCES

Dr Bertho and Dr Rodet's initial investigation attempts, however, angered towards the resears enhancing his father's document. At this stage, the text was over two thousand pages long, unfolding a global history of the black people. After a series of negotiations between the researchers Rodet the right to publish their ancestor's manuscript in Europe. On behalf of

and Mamadi Damaro Camara closely and his family. In the introduction, the authors thank the Camara family, and acknowledge the life and work of Digertho are and a documing on a second volume the enquiry into manuscript traject century until its official publication in 2020

\section{Behind the Research} and the Camaras, the family made the formal decision to give Dr Bertho and Dr Djiguiba Camara, calling for his wider

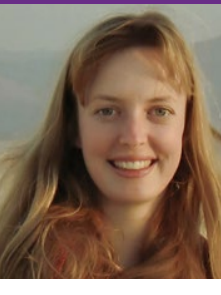
T: +33641796874 W: https://WwW.lam.
sciencespobordeaux.fr/annuaire-chercheurs/nom/ elara-bertho/ W: https:///cnrs.academia.edu/

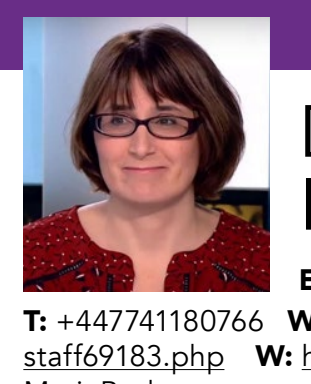

staff69183.ph
Dr Elara Bertho E: elara.bertho@gmail.com

Dr Marie Rodet

E: mr28@soas.ac.uk arabertho

\section{Research Objectives}

Dr Bertho and Dr Rodet investigate the historical writings of Djiguiba Camara, a Guinean colonial intermediary and scholar. Detail

\section{Marie Rodet}

The Univity of

Russell Square,

London WC1H OXG, UK

Elara Bertho

Sciences po Bordeaux / LAM

11 allée Ausone

33607 Pessac, France

Bio

(Comparative

\section{References}

Bertho, E. and Rodet, M. (2020). Essai d'histoire locale by Djiguiba Camara. Leiden, The Netherlands: Brill. Availab at: https://doi.org/10.1163/9789004424876

Bertho, E. and Rodet, M. (2019). Mise en scène

familiale, usages du savoir et campagnes politiques: 234, 543-570. Avainée). Cahiers d etudes a.40aines etudesafricaines.26012

Lawrence, B.N., Osborn, E.L. and Roberts, R.L. (eds.). Employees in the Making of Colonial Africa. University Wisconsin Press, Madison, Wisconsin.

Robinson, R. (1972). Non-European Foundations Coulaboration In R. Owen \& B. Sutcliffe (eds). Studien the Theory of Imperialism. Harlow, Longman: 117-142.

Tilley, H. and Gordon, R.J. (2007). Ordering Africa: Anthropology, European (mperialism, and the Polities of Knowledge, Mancise
Literature), is a Researcher at the ( Afriques dans le Monde (LAM). She is the author of Sorcières, tyrans, héros. Mémoires postcoloniales de résistants africains (Honoré Champion, 2019).

Marie Rodet, PhD (African Studies) is a Reader in the History of Africa SOAS, University of London. She haden history of gender, nigretion eademiadul tps://soas.academia.edu/ and slavery in French-speaking West Africa, inclualing more recently a web

\section{Funding}

- CNRS

- Les Afriques dans le Monde (LAM)

- British Academy

Collaborators

- Jan Jansen
Personal Response

What can Camara's account teach us about the importance of recognising the work of African

II It is crucial to uncover and publish African sources for African History today. We pulis African sources scholars full credit in the world history of knowledge production. Manuscripts such as Djiguiba Camara's work are a crucial counter-history to the weight of French colonial writing. To retrieve such neglected African sources of the twentieth century, it is essential to archives, personal papers and oral investigation.<smiles>C1=C[C@H]2C[C@@H]1[C@H]1C=C[C@H]21</smiles>

$\because \because 8$

LNM 